\title{
Isolation and Screening of Lactic Acid Bacteria for Acidic pH and Bile Tolerance
}

\author{
A.S. Noor Nawaz ${ }^{1}$, K.S. Jagadeesh ${ }^{1}$ and P.U. Krishnaraj ${ }^{2}$ \\ ${ }^{1}$ Department of Agricultural Microbiology, Agriculture College, \\ Dharwad-580 005, Karnataka, India \\ ${ }^{2}$ Department of Agricultural Microbiology, Agriculture College, Vijayapura-586 101, \\ Karnataka, India \\ *Corresponding author
}

\begin{tabular}{|c|c|}
\hline & A B S T R A C T \\
\hline $\begin{array}{l}\text { Ke y w o r d s } \\
\text { Lactic acid } \\
\text { bacteria, Isolates, } \\
\text { Probiotics, } \\
\text { Acid tolerance, } \\
\text { Bile tolerance. } \\
\end{array}$ & \multirow{3}{*}{$\begin{array}{l}\text { As many as } 25 \text { lactic acid bacterial strains were isolated from various } \\
\text { sources. These isolates were investigated for their tolerance to low } \mathrm{pH}(3.0 \text {, } \\
4.0 \text { and } 5.0) \text { and different bile concentrations }(0.3 \%, 0.4 \%, 0.75 \% \text { and } 1.0 \\
\%) \text {. Among } 25 \text { isolates, strain } 42,45 \text { and } 48 \text { showed very high tolerance to } \\
\text { acidic } \mathrm{pH} \text { and the same isolates also tolerated high level of bile salt } \\
\text { concentration up to } 1.0 \text { per cent. Thus, high resistance to low pH values and } \\
\text { to higher concentrations of bile salts enables these strains to survive in the } \\
\text { stomach and intestinal environment and to colonize the gut of the host, } \\
\text { possess a promising probiotic potential. Hence, these isolates hold potential } \\
\text { to be used as probiotics. }\end{array}$} \\
\hline Article Info & \\
\hline $\begin{array}{l}\text { Accepted: } \\
\text { 29 June } 2017 \\
\text { Available Online: } \\
\text { 10 July } 2017\end{array}$ & \\
\hline
\end{tabular}

\section{Introduction}

Lactic acid bacteria (LAB) are Gram positive, non-spore forming, Catalase negative, acid tolerant, fastidious, non-motile and facultative anaerobic friendly gut bacteria. They constitute heterogeneous group of industrially important bacteria. In food industries, they used as preservative, acidulant and flavouring agents by the virtue of their probiotic traits. They are also in use as starter culture in food fermentations such as beverages, yoghurt, vegetables, cereals, meat, cocoa beans etc. (Doyle and Beauchat, 2007). They are also utilized in the development of functional foods and more specifically their application as vaccines, pro and prebiotics, neutraceuticals has attracted new research arena for food scientists and health professionals (Mozzi et al., 2010; De Vuyst et al., 2004).

Traditionally, the fermented foods serve as good sources of new potential sources of LAB. Therefore use of strains of such origin would be of great importance, consumers who suffer from lactose intolerance. In order to exert its beneficial effect on the host, a probiotic strain must be able to survive the gut passage of humans to reach to the action site in viable state and should be in sufficient population (normally $10^{7}$ cells per $\mathrm{ml}$ ). Thus, 
in order to survive in and colonize the gut, the bacteria should express high tolerance to low (acidic) $\mathrm{pH}$ and high tolerance to higher concentrations of bile (Kirjavainen et al., 1998). They are supplemented as probiotics that are live microbial food supplements which beneficially affect the host by improving the intestinal microbial balance. Hence, as many as 25 isolates of lactic acid bacteria were obtained from various sources such as traditional artisan curds, fermented vegetables, dosa and idli batter, etc. The present work was aimed to evaluate the probiotic potential of these LAB isolates in terms of acid and bile tolerance properties.

\section{Materials and Methods}

\section{Isolation of LAB strains, media and culture conditions}

As many as 25 LAB strains were isolated from various sources such as traditional fermented arisan curds of Karnataka such as Kohlar, Banashankari, Almatti areas, fermented vegetables etc. by the method of plate count method. The $48 \mathrm{~h}$ grown culture was further purified and maintained on de Mann Rogosa Sharpe broth (MRS) (De Man et al., 1960) at $-80^{\circ} \mathrm{C}$ by DMSO (cryoprotectant) method.

\section{Test for Acid tolerance}

Two ml of overnight grown cultures of the test strains were centrifuged (10 min at 8000 rpm) using centrifuge (HERMLE Z32HK) and the cellular pellet was resuspended in two $\mathrm{ml}$ of MRS broth previously adjusted with $\mathrm{HCl}$ to different $\mathrm{pH}$ levels of 3.0, 4.0 and 5.0. The initial bacterial population soon after inoculation and after $3 \mathrm{~h}$ of after incubation was recorded using serial dilution and plate count method on MRS agar. The cultures were incubated at $37^{\circ} \mathrm{C}$ in an incubator. The viable counts $(\mathrm{CFU} / \mathrm{ml})$ are tabulated.

\section{Test for bile salt tolerance}

Similarly, in order to determine the bile tolerance potential of LAB isolates two $\mathrm{ml}$ of the overnight grown cultures of the test strains were centrifuged (10 min at $8000 \mathrm{rpm})$ using centrifuge and the cellular pellet was resuspended in two $\mathrm{ml}$ of MRS broth previously adjusted with bile salts (Oxgall Himedia) at different levels such as $0.3 \%, 0.4$ $\%, 0.75 \%$ and $1.0 \%$.

The inoculated cultures were incubated at $37^{0}$ $\mathrm{C}$ for $3 \mathrm{~h}$. The initial bacterial concentration and after incubation up to $3 \mathrm{~h}$ was recorded using optical density spectrophotometer at $650 \mathrm{~nm}$, the counts were tabulated as CFU per $\mathrm{ml}$ (Table 4). The control treatment was also maintained and incubated in MRS broth without any bile salts.

\section{Enumeration of viable $\mathrm{LAB}$}

Viable cells were enumerated by plating 10fold dilution on MRS agar medium. The plates were incubated at $37^{\circ} \mathrm{C}$ in an incubator for $3 \mathrm{~h}$.

The population was enumerated at initial (immediately after inoculation) and final counts at $90^{\text {th }}$ minute by serial dilution and plate count method at $10^{5}$ dilution. The values obtained were expressed as colony forming units per mililitre (CFU/ml).

\section{Results and Discussion}

The evaluation of probiotic potential of the 25 isolates was carried out in vitro by stimulating the environment of the gut, namely by subjecting the isolates to low $\mathrm{pH}$ values and by exposure to bile salts. The typical transit time of the food in the stomach is between 20 minutes to 3 hours (Hyronimus et al., 2000; Goldin et al., 1992) and therefore the treatment was kept until $3 \mathrm{~h}$ time span. 


\section{Acid tolerance}

Before reaching the intestinal tract, probiotic bacteria must first survive the harsh acidic condition of the stomach. Three $\mathrm{pH}$ levels of the growth medium were used where previously adjusted with $\mathrm{HCl}$ ranging from 3.0, 4.0 and 5.0 considering the stomach acidity varies from individual to individual (Dunne et al., 2001). The results indicated that among the 25 isolates studied, all showed good tolerance to acid but most of the LAB isolates showed poor growth and population at $\mathrm{pH}$ 5.0. The isolates 42,45 and 48 showed considerably higher at low $\mathrm{pH}$ of 3 and 4 compared to $\mathrm{pH}$ 5. (Table 1-3). This study confirms that the resistance to the low $\mathrm{pH}$ is strain dependent. These results are in confirmation with Mishera et al., (2005), three of their seven isolates Lactobacillus sp. tolerated $\mathrm{pH}$ 3.0. Although the acid tolerance in lactobacilli is highly strain specific, members of the genus Lactobacillus are acidophilic in nature and are able to grow at $\mathrm{pH} 4.0$ in foods containing a fermentable carbohydrate (Alakomi et al., 2001).

Table.1 Growth of lactic acid bacterial isolates at $\mathrm{pH} 3.0$

\begin{tabular}{|l|c|c|c|}
\hline \multirow{2}{*}{ Sl. No. } & Code No. of the LAB & \multicolumn{2}{|c|}{ *Mean Population (cfu X $10^{5}$ per ml) } \\
\cline { 3 - 4 } & isolate & Initial & After 3 h of incubation \\
\hline 1 & $\mathbf{2}$ & $\mathbf{1 6 . 5}$ & $\mathbf{1 1 6 . 0}$ \\
\hline 2 & $\mathbf{3}$ & $\mathbf{1 6 . 0}$ & $\mathbf{1 2 5 . 5}$ \\
\hline 3 & $\mathbf{4}$ & $\mathbf{1 8 . 0}$ & $\mathbf{1 1 8 . 5}$ \\
\hline 4 & $\mathbf{6}$ & $\mathbf{1 6 . 5}$ & $\mathbf{1 6 4 . 0}$ \\
\hline 5 & $\mathbf{3 5}$ & $\mathbf{1 6 . 0}$ & $\mathbf{1 1 7 . 0}$ \\
\hline 6 & $\mathbf{3 9}$ & $\mathbf{1 5 . 0}$ & $\mathbf{9 6 . 0}$ \\
\hline 7 & $\mathbf{4 0}$ & $\mathbf{7 7 . 5}$ & $\mathbf{2 5 8 . 5}$ \\
\hline 8 & $\mathbf{4 2}$ & $\mathbf{9 7 . 5}$ & $\mathbf{2 9 2 . 0}$ \\
\hline 9 & $\mathbf{4 5}$ & $\mathbf{8 2 . 5}$ & $\mathbf{2 6 6 . 0}$ \\
\hline 10 & $\mathbf{4 8}$ & $\mathbf{9 . 0}$ & $\mathbf{1 0 7 . 5}$ \\
\hline 11 & $\mathbf{5 2}$ & $\mathbf{1 0 . 5}$ & $\mathbf{8 7 . 0}$ \\
\hline 12 & $\mathbf{5 3}$ & $\mathbf{5 6 . 0}$ & $\mathbf{1 7 0 . 5}$ \\
\hline 13 & $\mathbf{5 4}$ & $\mathbf{1 5 . 0}$ & $\mathbf{6 7 . 0}$ \\
\hline 14 & $\mathbf{5 7}$ & $\mathbf{1 1 . 0}$ & $\mathbf{6 9 . 5}$ \\
\hline 15 & $\mathbf{5 8}$ & $\mathbf{2 6 . 0}$ & $\mathbf{1 5 4 . 0}$ \\
\hline 16 & $\mathbf{5 9}$ & $\mathbf{7 1 . 5}$ & $\mathbf{1 9 2 . 5}$ \\
\hline 17 & $\mathbf{6 0}$ & $\mathbf{1 2 . 5}$ & $\mathbf{5 1 . 0}$ \\
\hline 18 & $\mathbf{6 1}$ & $\mathbf{1 2 . 0}$ & $\mathbf{1 0 2 . 0}$ \\
\hline 19 & $\mathbf{6 3}$ & $\mathbf{1 4 . 0}$ & $\mathbf{1 0 2 . 5}$ \\
\hline 20 & $\mathbf{6 5}$ & $\mathbf{6 8 . 0}$ & $\mathbf{1 8 6 . 0}$ \\
\hline 21 & $\mathbf{6 6}$ & $\mathbf{6 5 . 5}$ & $\mathbf{1 0 1 . 0}$ \\
\hline 22 & $\mathbf{6 9}$ & $\mathbf{1 1 . 5}$ & $\mathbf{1 7 3 . 5}$ \\
\hline 23 & $\mathbf{7 2}$ & & \\
\hline 24 & $\mathbf{7 3}$ & $\mathbf{3 5 . 0}$ & \\
\hline 25 & & & \\
\hline
\end{tabular}

*mean of two replications 
Table.2 Growth of lactic acid bacterial isolates at $\mathrm{pH} 4.0$

\begin{tabular}{|c|c|c|c|}
\hline \multirow[b]{2}{*}{ Sl. No. } & \multirow[b]{2}{*}{ Code No. of the LAB isolate } & \multicolumn{2}{|c|}{ Population (cfu X $10^{5}$ per ml) } \\
\hline & & Initial & $\begin{array}{l}\text { After } 3 \mathrm{~h} \text { of } \\
\text { incubation }\end{array}$ \\
\hline 1 & 2 & 6.5 & 99.0 \\
\hline 2 & 3 & 8.0 & $\mathbf{7 0 . 0}$ \\
\hline 3 & 4 & 6.5 & 102.0 \\
\hline 4 & 6 & 22.0 & 56.8 \\
\hline 5 & 35 & 12.5 & 83.0 \\
\hline 6 & 39 & 12.5 & 85.0 \\
\hline 7 & 40 & 6.5 & 82.0 \\
\hline 8 & 42 & 85.5 & 253.0 \\
\hline 9 & 45 & 72.0 & 244.0 \\
\hline 10 & 48 & 74.5 & 245.0 \\
\hline 11 & 52 & 10.5 & 66.5 \\
\hline 12 & 53 & 8.0 & 87.0 \\
\hline 13 & 54 & 34.5 & 159.0 \\
\hline 14 & 57 & 13.5 & 94.0 \\
\hline 15 & 58 & 11.0 & 83.5 \\
\hline 16 & 59 & 32.0 & 146.0 \\
\hline 17 & 60 & 14.0 & 126.0 \\
\hline 18 & 61 & 62.0 & 219.0 \\
\hline 19 & 63 & 16.0 & 78.5 \\
\hline 20 & 65 & 7.5 & 68.5 \\
\hline 21 & 66 & 13.5 & 67.5 \\
\hline 22 & 69 & 50.5 & 170.5 \\
\hline 23 & 72 & 50.0 & 162.0 \\
\hline 24 & 73 & 11.0 & 71.0 \\
\hline 25 & 75 & 33.0 & 156.0 \\
\hline
\end{tabular}

Table.3 Growth of lactic acid bacterial isolates at $\mathrm{pH} 5.0$

\begin{tabular}{|l|c|c|c|}
\hline \multirow{2}{*}{ S1 No. } & \multirow{2}{*}{ Code No. of the LAB isolate } & \multicolumn{2}{|c|}{ Population (cfu X $10^{5}$ per ml) } \\
\cline { 3 - 4 } & $\mathbf{2}$ & Initial & After 3 h of incubation \\
\hline 1 & $\mathbf{3}$ & $\mathbf{5 . 0}$ & $\mathbf{4 5 . 0}$ \\
\hline 2 & $\mathbf{4}$ & $\mathbf{5 . 5}$ & $\mathbf{4 6 . 0}$ \\
\hline 3 & $\mathbf{6}$ & $\mathbf{6 . 0}$ & $\mathbf{2 5 . 5}$ \\
\hline 4 & $\mathbf{3 5}$ & $\mathbf{1 2 . 5}$ & $\mathbf{5 1 . 0}$ \\
\hline 5 & $\mathbf{3 9}$ & $\mathbf{7 . 0}$ & $\mathbf{3 3 . 5}$ \\
\hline 6 & $\mathbf{4 0}$ & $\mathbf{7 . 0}$ & $\mathbf{4 7 . 0}$ \\
\hline 7 & $\mathbf{4 2}$ & $\mathbf{4 . 0}$ & $\mathbf{3 9 . 0}$ \\
\hline 8 & $\mathbf{4 5}$ & $\mathbf{5 7 . 0}$ & $\mathbf{2 2 2 . 5}$ \\
\hline 9 & $\mathbf{4 8}$ & $\mathbf{4 4 . 0}$ & $\mathbf{1 8 7 . 5}$ \\
\hline 10 & $\mathbf{5 2}$ & $\mathbf{5 3 . 5}$ & $\mathbf{1 9 9 . 0}$ \\
\hline 11 & $\mathbf{6 3}$ & $\mathbf{6 . 5}$ & $\mathbf{3 3 . 5}$ \\
\hline 12 & $\mathbf{5 4}$ & $\mathbf{5 . 0}$ & $\mathbf{2 5 . 0}$ \\
\hline 13 & $\mathbf{5 7}$ & $\mathbf{4 . 0}$ & $\mathbf{1 3 0 . 0}$ \\
\hline 14 & & & $\mathbf{4 1 . 5}$ \\
\hline
\end{tabular}




\begin{tabular}{|l|c|c|c|}
\hline 15 & $\mathbf{5 8}$ & $\mathbf{5 . 5}$ & $\mathbf{4 1 . 0}$ \\
\hline 16 & $\mathbf{5 9}$ & $\mathbf{1 7 . 0}$ & $\mathbf{9 9 . 0}$ \\
\hline 17 & $\mathbf{6 0}$ & $\mathbf{6 . 0}$ & $\mathbf{3 5 . 0}$ \\
\hline 18 & $\mathbf{6 1}$ & $\mathbf{4 2 . 0}$ & $\mathbf{1 7 6 . 5}$ \\
\hline 19 & $\mathbf{6 3}$ & $\mathbf{5 . 5}$ & $\mathbf{4 1 . 0}$ \\
\hline 20 & $\mathbf{6 5}$ & $\mathbf{6 . 5}$ & $\mathbf{4 2 . 0}$ \\
\hline 21 & $\mathbf{6 6}$ & $\mathbf{6 . 5}$ & $\mathbf{4 5 . 0}$ \\
\hline 22 & $\mathbf{6 9}$ & $\mathbf{3 4 . 0}$ & $\mathbf{1 4 7 . 0}$ \\
\hline 23 & $\mathbf{7 2}$ & $\mathbf{2 2 . 5}$ & $\mathbf{3 6 . 0}$ \\
\hline 24 & $\mathbf{7 3}$ & $\mathbf{6 . 0}$ & $\mathbf{1 2 1 . 5}$ \\
\hline 25 & $\mathbf{7 5}$ & $\mathbf{2 2 . 5}$ & \\
\hline
\end{tabular}

Table.4 Growth of lactic acid bacterial isolates at different bile concentrations (OD values)

\begin{tabular}{|c|c|c|c|c|c|c|c|c|}
\hline \multirow{2}{*}{$\begin{array}{c}\text { LAB } \\
\text { ISOLATE }\end{array}$} & \multicolumn{2}{|c|}{$0.3 \%$} & \multicolumn{2}{|c|}{$0.4 \%$} & \multicolumn{2}{|c|}{$0.75 \%$} & \multicolumn{2}{|c|}{$1.0 \%$} \\
\hline & $0: 0 \mathrm{~h}$ & 03:00 h & $0: 0 \mathrm{~h}$ & 03:00 h & $0: 0 \mathrm{~h}$ & 03:00 h & $0: 0 \mathrm{~h}$ & 03:00 h \\
\hline 2 & 0.120 & 0.225 & 0.117 & 0.680 & 0.123 & 0.225 & 0.122 & 0.256 \\
\hline 3 & 0.085 & 0.215 & 0.090 & 0.796 & 0.075 & 0.081 & 0.085 & 0.092 \\
\hline 4 & 0.071 & 0.265 & 0.128 & 0.450 & 0.114 & 0.116 & 0.131 & 0.203 \\
\hline 6 & 0.053 & 0.033 & 0.069 & 0.066 & 0.090 & 0.590 & 0.090 & 0.619 \\
\hline 35 & 0.130 & 0.189 & 0.112 & 0.769 & 0.108 & 0.239 & 0.123 & 0.274 \\
\hline 39 & 0.095 & 0.505 & 0.074 & 0.236 & 0.084 & 0.110 & 0.094 & 0.121 \\
\hline 40 & 0.076 & 0.109 & 0.065 & 0.749 & 0.063 & 0.084 & 0.080 & 0.100 \\
\hline 42 & 0.097 & 1.115 & 0.120 & 1.093 & 0.133 & 1.099 & 0.135 & 1.041 \\
\hline 45 & 0.083 & 0.070 & 0.111 & 0.080 & 0.120 & 0.139 & 0.119 & 0.933 \\
\hline 48 & 0.110 & 0.122 & 0.125 & 1.175 & 0.135 & 1.195 & 0.190 & 1.273 \\
\hline 52 & 0.078 & 0.103 & 0.053 & 0.840 & 0.053 & 0.080 & 0.048 & 0.086 \\
\hline 53 & 0.080 & 0.097 & 0.082 & 1.060 & 0.086 & 0.165 & 0.090 & 0.199 \\
\hline 54 & $\mathbf{0 . 0 3 7}$ & 0.031 & 0.069 & 0.069 & 0.091 & 0.332 & 0.092 & 0.600 \\
\hline 57 & 0.054 & 0.079 & 0.022 & 0.841 & 0.053 & 0.091 & 0.058 & 0.116 \\
\hline 58 & 0.059 & 0.066 & 0.058 & 0.871 & 0.056 & 0.075 & 0.056 & 0.073 \\
\hline 59 & 0.051 & 0.053 & 0.071 & 0.071 & 0.090 & 0.631 & 0.091 & 0.713 \\
\hline 60 & 0.090 & 0.145 & 0.109 & 0.603 & 0.109 & 0.178 & 0.071 & 0.093 \\
\hline 61 & 0.063 & 0.055 & 0.082 & 0.090 & 0.100 & 0.617 & 0.120 & 0.831 \\
\hline 63 & 0.150 & 0.171 & 0.110 & 0.756 & 0.061 & 0.090 & 0.062 & 0.078 \\
\hline 65 & 0.100 & 0.121 & 0.069 & 0.862 & 0.058 & 0.127 & $\begin{array}{l}0.049 \\
\end{array}$ & 0.119 \\
\hline 66 & 0.098 & 0.251 & $\mathbf{0 . 0 7 3}$ & 0.838 & 0.071 & 0.108 & 0.074 & 0.125 \\
\hline 69 & 0.081 & 1.093 & 0.120 & 1.095 & 0.130 & 0.139 & 0.120 & 0.947 \\
\hline 72 & 0.080 & 0.062 & 0.090 & 0.059 & 0.115 & 0.851 & 0.131 & 0.854 \\
\hline 73 & 0.098 & 0.237 & 0.110 & 0.719 & 0.098 & 0.148 & 0.095 & 0.149 \\
\hline 75 & 0.050 & 0.055 & 0.077 & 0.081 & 0.092 & 0.615 & 0.120 & 0.750 \\
\hline
\end{tabular}

The probiotic effect of LAB may partly be based on the production of relevant concentrations of lactic acid in the microenvironment, which in combination with bile salts, inhibits the growths of Gram negative pathogenic bacteria (Stiles and Holzapfel, 1997).

\section{Bile tolerance}

Bile salts belong to the factors that may significantly affect the viability of LAB in the GIT, influencing the health of the host. Tolerance to bile salts is a prerequisite for colonization and metabolic activity of the 
bacteria in the small intestine of the host (Havenaar et al., 1992). This will help LAB to reach the small intestine and colon and contribute in balancing the intestinal microflora (Tambekar and Bhutada, 2010).

After $3 \mathrm{~h}$ of incubation in MRS medium supplemented with $0.3 \%$ bile all isolates showed variable rates of growth (Table 3). All the isolates showed good survivability at lower concentrations $(0.3 \%, 0.4 \%)$. However, few isolates such as 42,45 and 48 survived even to the higher bile concentrations $(0.75 \%$ and 1.0 $\%$ oxgall). Thus, these results indicate that these isolate could be used as potential candidates as probiotics (Table 3).

In conclusion, the $\mathrm{LAB}$ isolates used in the study showed a high resistance to low $\mathrm{pH}$ levels and to higher bile salt concentrations. These traits may enable them to survive in the stomach and intestine or even to compete with other bacterial groups in this environment and to colonize the gut of the host. The results indicated that isolates 42,45 and 48 showed very high tolerance to acidic $\mathrm{pH}$ as well as to higher bile salt concentrations. Hence, the results indicating that their potential to be explored as probiotic strains in future.

\section{References}

Alakomi, H.L., Skytta, E., Saarela, M., MattilaSandholm, T., Latva-Kala, K. and Helander, I. 2005. Lactic acid permeabilizes Gram-negative bacteria by disturbing the outer membrane. Appl. Environ. Microbiol., 66.

De Man, J., Rogosa, M., and Sharpe, M.1960. A medium for the cultivation of Lactobacilli. J. Appl. Bact., 23: 130-135.
De Vuyst, L., Avonts, L., and Makras, E. 2004. Probiotics, prebiotics, and gut health. In $\mathrm{C}$. Remacle \& B. Reusens (Eds.), Functional Foods, Ageing and Degenerative Disease Cambridge, UK: Woodhead Publishing, 416-482.

Doyle, M.P. and Beuchat, L.R. 2007. Food Microbiology: Fundamentals and Frontiers. (eds.) Washington, DC: ASM Press.

Goldin, B., Gorbach, S., Saxelin, M., Barakat, S., Gualtieri, L. and Salminen, S. 1992. Survival of Lactobacillus species (Strain GG) in human gastrointestinal tract. Digestive Dis. Sci., 37: 121-128.

Havenaar, R. and Huis in't Velt, J. 1992. Probiotics: A general view. In wood ed. The lactic acid 239 bacteria in health and disease. London Elsevier Appl. Sci., 209. 224.

Hyronimus, B., LeMarrec, C., Haji Sassi, A. and Deschamps, A. 2000. Acid and bile tolerance of spore-forming lactic acid bacteria. Int. J. Food Microbiol., 61: 193797.

Mishera, V. and Prasad, D.N. 2005. Application of in vitro methods for selection of Lactobacillus casei strains as potential probiotics. Int. J. Food Microbiol., 103: 109-115.

Mozzi, F., Raya, R.R. and Vignolo, G.M. 2010. Biotechnology of lactic acid bacteria Novel applications. Wiley-Blackwell Publishing, Iowa, USA. (eds.).

Stiles, M.E. and Holzapfel, W.H. 1997. Lactic acid bacteria of foods and their current taxonomy. Int. J. Food Microbiol., 36, 129.

Tambekar, D.H. and Bhutada, S.A. 2010. Studies on antimicrobial activity and characteristics of bacteriocins produced by Lactobacillus strains isolated from milk of domestic animals. Int. J. Microbiol., 8: 1-6.

\section{How to cite this article:}

Noor Nawaz, A.S., K.S. Jagadeesh and Krishnaraj, P.U. 2017. Isolation and Screening of Lactic Acid Bacteria for Acidic $\mathrm{pH}$ and Bile Tolerance. Int.J.Curr.Microbiol.App.Sci. 6(7): 3975-3980. doi: https://doi.org/10.20546/ijcmas.2017.607.411 